\title{
INNOVATIVE TECHNIQUES OF WASTE PLASTIC USED IN CONCRETE MIXTURE
}

\author{
Pramod S. Patil $^{1}$, J.R.Mali ${ }^{2}$, Ganesh V.Tapkire ${ }^{3}$, H. R. Kumavat ${ }^{4}$ \\ ${ }^{l}$ P.G.Student.Civil Department, SSBT COET Jalgaon, Maharashtra, India \\ ${ }^{2}$ Assistant Professor, Civil Department, SSBT COET Jalgaon, Maharashtra, India \\ ${ }^{3}$ P.G.Student, Civil Department, NRI Institute of Research \& Technology, Bhopal (M.P) \\ ${ }^{4}$ Assistant Professor, Civil Department, RCPIT Shirpur, Maharashtra
}

\begin{abstract}
Disposal of plastic waste in an environment is considered to be a big problem due to its very low biodegradability and presence in large quantities. In recent time use of such, Industrial wastes from polypropylene (PP) and polyethylene terephthalate (PET) were studied as alternative replacements of a part of the conventional aggregates of concrete. Plastic recycling was taking place on a significant scale in an India. As much as $60 \%$ of both industrial and urban plastic waste is recycled which obtained from various sources. People in India have released plastic wastes on large scale have huge economic value, as a result of this, recycling of waste plastics plays a major role in providing employment.
\end{abstract}

Keywords: polypropylene (PP) and polyethylene terephthalate (PET) etc...

\section{INTRODUCTION}

Disposal of waste plastic consumer bags from the domestic has become a major problem to the agencies in the town and cities. The waste plastic bags available in the domestic waste mainly consist of low density polyethylene (LDPE). Plastic bags dumped in the dustbins find their way into the drainage system and clog them. Often, these are burnt along the roadside, which produces fumes causing air pollution.

Industrial wastes from polypropylene (PP) and polyethylene terephthalate (PET) were studied as alternative replacements of a part of the conventional aggregates of concrete. Five replacement levels.10\%, $20 \%, 30 \%, 40 \%$ \& $50 \%$ by volume of aggregates were used for the preparation of the concretes.

\subsection{Source of Employment in the Management of}

\section{Waste Plastics}

Plastic recycling was taking place on a significant scale in an India. As much as $60 \%$ of both industrial and urban plastic waste is recycled which obtained from various sources. People in India have released plastic wastes on large scale have huge economic value, as a result of this, recycling of waste plastics plays a major role in providing employment. This helps for the economic development of the country. Indian construction industry creates lot of employment opportunities and accounts for major portion of the capital outlay in successive 5-year plans of our country.

\subsection{Methodology}

The main research of that project is to utilized recycled concrete as a coarse aggregate for the production of concrete. It is essential to know the replacement of Plastic
Aggregate (PA) in concrete is acceptable there are for the making of concrete used coarse aggregate having size $20 \mathrm{~mm}$, natural river sand used for making a concrete and plastic aggregate used in crushed concrete from the tested cubes. Test carried out on these aggregate specific gravity and Bulk density, and sieve analysis.

a mix design is produced in accordance with the properties obtained from test results. Concrete is then produced with replacement of $10 \%, 20 \%, 30 \%, 40 \%$ and $50 \%$ of plastic aggregate replacement of plastic aggregate with the same mix proportion.

\section{EXPERIMENTAL PROGRAM}

Total Forty-eight specimens and six beams \& cylinders each for M20 grade of concrete with four different volume percentages of plastic $(0 \%, 10 \%, 20 \%, 30 \%, 40 \%, 50 \%)$ were cast as recommended by IS: 10262- 1982 .

The main objective of this research is to determine specfic gravity, water absorption, and abrasion value, crushing strength, impact test of two replacement levels, $0 \%, 10 \%$, $20 \%$ and $30 \%, 40 \%, 50 \%$ by volume of aggregates were used for the preparation of the concretes.

- Aggregates : Coarse Aggregate (CA) Fine Aggregate (FA)

- Coarse Aggregate (CA): They should have following properties

- The Los Angeles Abrasion value shall not be more than $25 \%$ (ASTM C131).

- The weighted average weight loss in magnesium sulphate soundness test shall not be more than $18 \%$ (AASTHO T 104).

- Flakiness index shall not be more than 25\% (MS 30). 
- The water absorption should not be more than $2 \%$ (MS30)

- The polished stone value should not be less than $40 \%$.

- Fine Aggregate (FA):FA should have the following properties

- $\quad$ The angularity should not be less than 45\% (ASTM C 1252).

- The absorption of water, should not be more than 2\% (MS30)

- Plastic Aggregate (PA): This is made up from waste plastic and can be prepared by following steps

- Collection and Cleaning, Classification.

- Shredding and Cleaning.

- Heating and Melting.

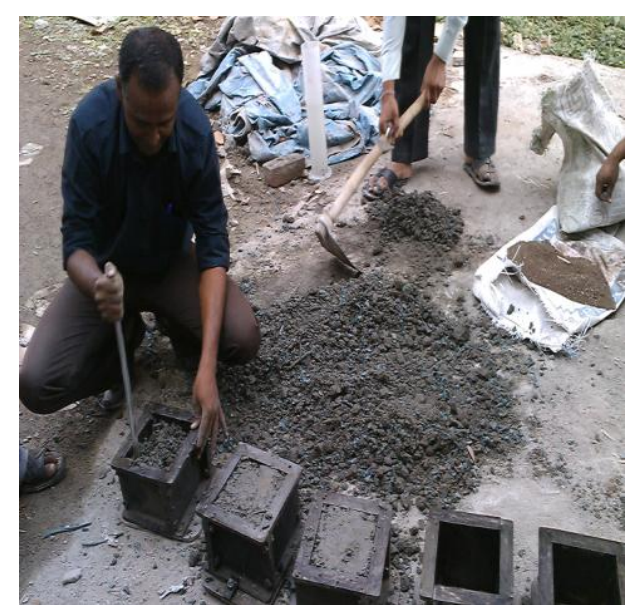

\begin{tabular}{|l|l|l|}
\hline $\begin{array}{l}\text { Physical } \\
\text { Properties }\end{array}$ & CA & FA \\
\hline $\begin{array}{l}\text { Specific } \\
\text { Gravity }\end{array}$ & 2.85 & 2.433 \\
\hline Bulk Density & $1600 \mathrm{~kg} / \mathrm{cm} 2$ & $1700 \mathrm{~kg} / \mathrm{cm} 2$ \\
\hline $\begin{array}{l}\text { Fineness } \\
\text { Modulus }\end{array}$ & 4.65 & 2.2 \\
\hline $\begin{array}{l}\text { Water } \\
\text { Absorption }\end{array}$ & $0.49 \%$ & $0.22 \%$ \\
\hline Free Moisture & NIL & 2 \\
\hline
\end{tabular}

Various Tests on Cement

\begin{tabular}{|l|l|l|l|l|l|l|}
\hline Test & $\begin{array}{l}\text { Fine } \\
\text { ness }\end{array}$ & $\begin{array}{l}\text { Std. } \\
\text { Consi } \\
\text { stenc } \\
\text { y }\end{array}$ & $\begin{array}{l}\text { Initial } \\
\text { setting } \\
\text { Time }\end{array}$ & $\begin{array}{l}\text { Final } \\
\text { Settin } \\
\text { g } \\
\text { Time }\end{array}$ & $\begin{array}{l}\text { Sound } \\
\text { ness }\end{array}$ & $\begin{array}{l}\text { comp.S } \\
\text { t. in } \\
\text { N/mm2 } \\
7 \text { Days }\end{array}$ \\
\hline $\begin{array}{l}\text { Resu } \\
\text { lt }\end{array}$ & $\begin{array}{l}1.18 \\
8 \%\end{array}$ & 35 & $\begin{array}{l}48 \\
\text { min. }\end{array}$ & $\begin{array}{l}285 \\
\text { min. }\end{array}$ & $\begin{array}{l}4.47 \\
\text { mm }\end{array}$ & 24.02 \\
\hline
\end{tabular}

Density of concrete

\begin{tabular}{|c|c|c|c|c|c|c|}
\hline $\begin{array}{l}\text { Replacement } \\
\text { of RCA in \% }\end{array}$ & 0 & 10 & 20 & 30 & 40 & 50 \\
\hline $\begin{array}{l}\text { Avg.Density } \\
\text { of } \\
\text { concreteSt.Kg } \\
\text { /m3 }\end{array}$ & $\begin{array}{l}n \\
\infty \\
n \\
\end{array}$ & $\begin{array}{l}n \\
\frac{n}{6} \\
\text { c }\end{array}$ & 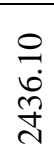 & 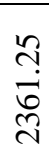 & $\begin{array}{l}\stackrel{\nabla}{0} \\
\stackrel{\sim}{\Delta}\end{array}$ & $\begin{array}{l}\hat{2} \\
\infty \\
\infty \\
\text { N }\end{array}$ \\
\hline
\end{tabular}

\section{Compressive Strength for 7 Days}

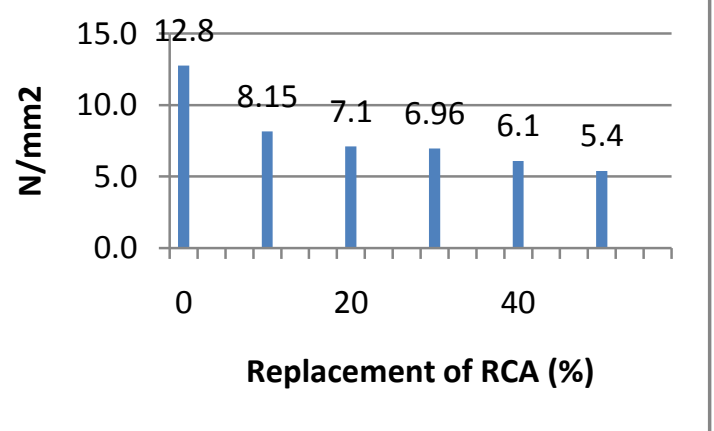

Compressive Strength test of Concrete for 7 Days

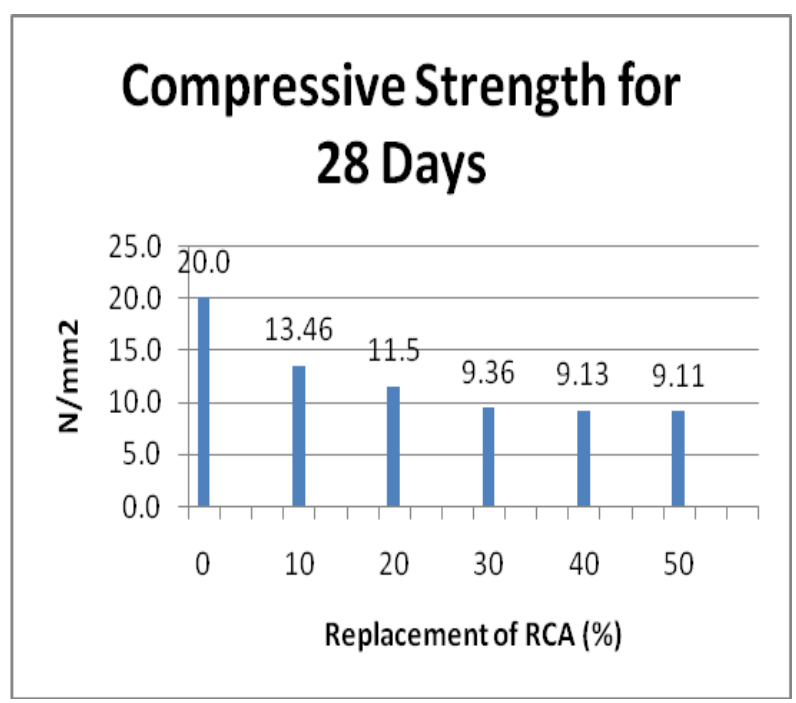

Compressive Strength test of Concrete for 28 Days

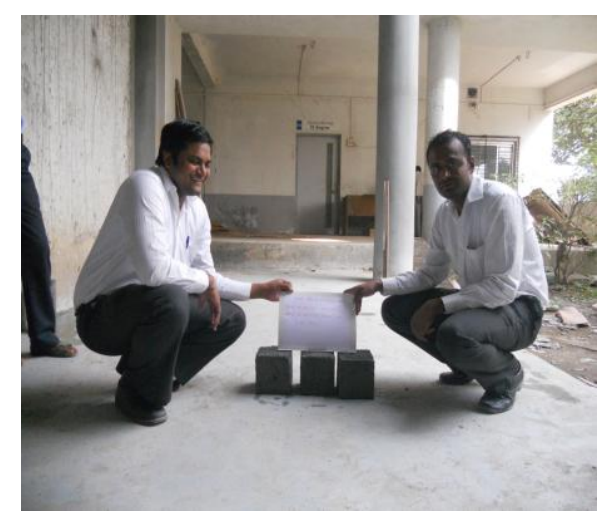




\begin{tabular}{|c|c|c|c|c|c|c|}
\hline $\begin{array}{l}\text { Replacem } \\
\text { ent of } \\
\text { RCA in } \%\end{array}$ & 0 & 10 & 0 & 30 & 40 & 50 \\
\hline $\begin{array}{ll}\text { Avg.F. } & \text { St } \\
\text { N/mm2 } & \\
\text { For } & 7 \\
\text { Days } & \\
\end{array}$ & $\begin{array}{l}40.4 \\
7\end{array}$ & $\begin{array}{l}41.2 \\
8\end{array}$ & $\begin{array}{l}37.9 \\
5\end{array}$ & $\begin{array}{l}38.3 \\
2\end{array}$ & $\begin{array}{l}36.4 \\
2\end{array}$ & $\begin{array}{l}35.8 \\
6\end{array}$ \\
\hline $\begin{array}{l}\text { Avg.F.St. } \\
\text { N/mm2 } \\
\text { For } 28 \\
\text { Days }\end{array}$ & 53.4 & $\begin{array}{l}59.0 \\
3\end{array}$ & $\begin{array}{l}51.0 \\
7\end{array}$ & $\begin{array}{l}51.5 \\
9\end{array}$ & $\begin{array}{l}49.2 \\
8\end{array}$ & $\begin{array}{l}48.3 \\
2\end{array}$ \\
\hline
\end{tabular}
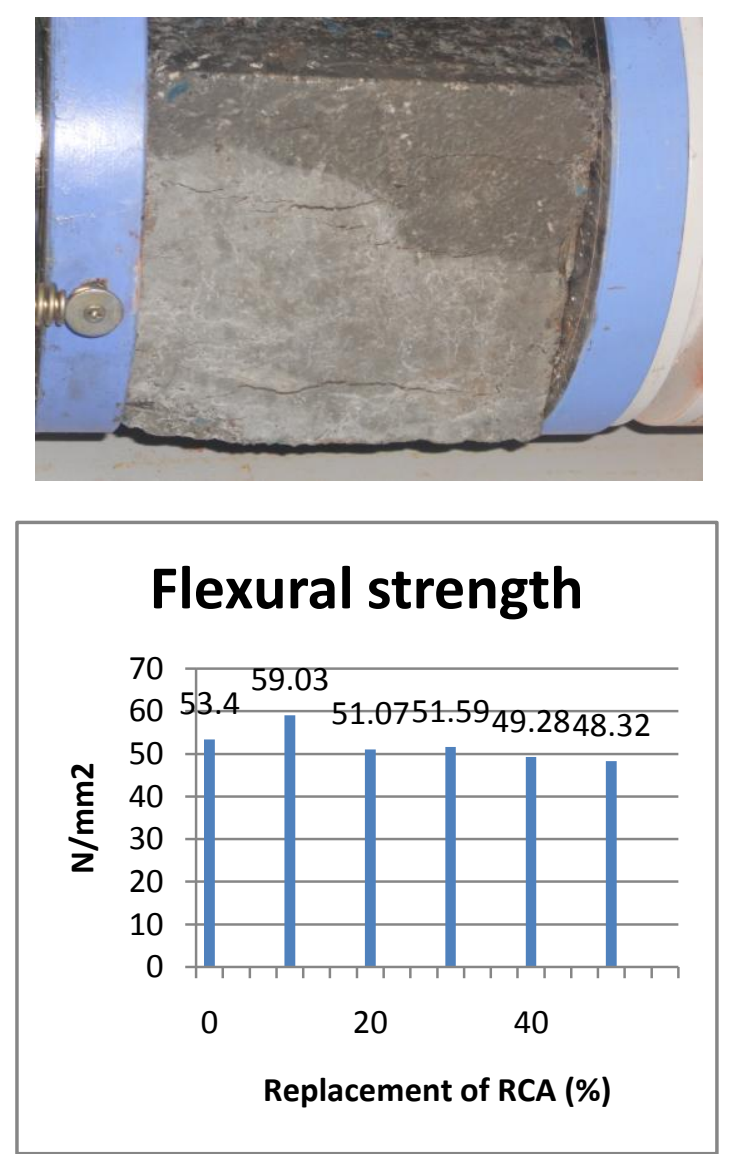

Flexural Strength test of Concrete for 7 and 28 Days

\section{CONCLUSIONS}

The test conducted on material like Cement, Sand, Conventional aggregate having all the results within permissible limit as per IS codes.

The modified concrete mix, with addition of plastic aggregate replacing conventional aggregate up to certain $20 \%$ gives strength with in permissible limit.

Modified concrete casted using plastic aggregate as a partial replacement to coarse aggregate shows $10 \%$ it could be satisfy as per IS codes.

Density of concrete is reducing after $20 \%$ replacement of coarse aggregates in a concrete

\section{ACKNOWLEDGEMENTS}

The authors can acknowledge any person/authorities in this section. This is not mandatory.

\section{REFERENCES}

[1] Madan Mohan Reddy ,K, Ajitha .B,and Bhavani .R , "Melt-Densified Post Consumer Recycled Plastic Bags Used As Light Weight Aggregate In Concrete"," International Journal of Engineering Research and Applications (IJERA) ISSN: 22489622 Vol. 2, Issue4, July-August 2012, pp.10971101.

[2] V. Kasselouri - Rigopoulou, S. Gavela, S. Kolias "Use Of Polymeric Wastes In The Concrete Production" Polymers in concrete: a vision for the 21st century, Cement \& Concrete Composites 21: (1999) 449-452.

[3] Baboo Rai, S. Tabin Rushad, Bhavesh Kr, and S. K. Duggal "Research Article Study of Waste Plastic Mix Concrete with Plasticizer" International Scholarly Research Network ISRN Civil Engineering Volume 2012, Article ID 469272, 5 pages doi:10.5402/2012/469272 2005.

[4] Manual on Cement Concrete \& Aggregates Australia Use of Recycled Aggregates in Construction May 2008Removal and Reuse of Hardened Concrete (ACI 555R- American Concrete Institute.

[5] Alessandra Passaro" recycled plastic lightweight aggregate for concrete"

[6] S. Gavela , C. Karakosta , C. Nydriotis , V. Kaselouri-Rigopoulou, S. Kolias ,P. A. Tarantili , C. Magoulas , D. Tassios and A. Andreopoulos "A Study Of Concretes Containing Thermoplastic Wastes As Aggregates"

[7] L. R. Bandodkar, A. A. Gaonkar, N. D. Gaonkar, \& Y. P. Gauns “ Pulverised PET Bottles as Partial Replacement for Sand" International Journal of Earth Sciences and Engineering 1009 ISSN 0974-5904, Volume 04, No 06 SPL, October 2011, pp. 10091012

[8] L. R. Bandodkar, A. A. Gaonkar, N. D. Gaonkar, \& Y. P. Gauns " Pulverised PET Bottles as Partial Replacement for Sand" International Journal of Earth Sciences and Engineering 1009 ISSN 0974-5904, Volume 04, No 06 SPL, October 2011, pp. 10091012

[9] Dr. Prahallada M.C and Dr. Prakash K.B "Strength and Workability Characteristicsof Waste Plastic Fibre Reinforced Concrete Produced From Recycled Aggregates" International Journal of Engineering Research and Applications (IJERA) ISSN: 22489622

[10] V. Vytlacilov "The fibre reinforced concrete with using recycled aggregates" International Journal Of Systems Applications, Engineering \& Development Issue 3, Volume 5, 2011

[11] Casanova-del-Angel, and Vzquez-Ruiz.C Manufacturing Light Concrete with PET Aggregate" 
[12] R. Lakshmi and S. Nagan"Investigations On Durability Characteristics Of EPlasticWaste Incorporated Concrete" Asian Journal Of Civil Engineering (Building And Housing) Vol. 12, No. 6 (2011) Pages 773-787

\section{BIOGRAPHIES}

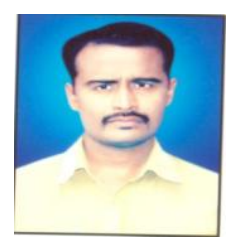

Pramod S.Patil Completed B.E. in civil Engineering 2009 and ME appear in Environmental science\& Engineering North Maharashtra University Jalgaon. presented and Publish paper 02 Research paper in National conference and 01 International Journal along with publication author had attended 05 workshop sponsored by ISTE. From last two year assistant professor in civil Engineering department in R.C.Patel. Institute of Technology Shirpur

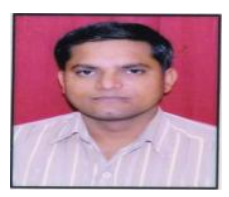

Ganesh v.Tapkire Completed B.E. in civil Engineering 2008 and M-Tech appear in Building Construction \&Technology in RGPV University Bhopal (MP).presented and Publish paper 02 Research paper in National conference and 01 International Journal along with publication author had attended 05 workshop sponsored by ISTE. Have two years site experience in NH-3 Pimpalga on-dhule BOT Project.

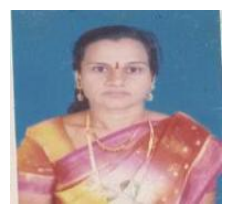

Jyoti R. Mali Completed B.E. in civil Engineering 2000 and ME completed in2009 Environmental science\& Engineering North Maharashtra University Jalgaon. presented and Publish paper 10 Research paper in National conference and International Journal along with publication author had attened 08 workshop sponsored by ISTE. From last two year assistant professor in civil Engineering department in SSBT Bambhori, Jalgaon 